\title{
White spot syndrome virus (WSSV) in Litopenaeus vannamei captured from the Gulf of California near an area of extensive aquaculture activity
}

\author{
Z. Mijangos-Alquisires ${ }^{1,2}$, N. Quintero-Arredondo ${ }^{1}$, \\ R. Castro-Longoria ${ }^{1, *}$, J. M. Grijalva-Chon ${ }^{1}$, J. Ramos-Paredes ${ }^{1}$ \\ ${ }^{1}$ Universidad de Sonora, Departamento de Investigaciones Científicas y Tecnológicas, Rosales y Niños Héroes s/n, \\ Hermosillo, Sonora 83000, Mexico \\ ${ }^{2}$ Present address: Dirección General de Educación en Ciencia y Tecnología del Mar, Secretaría de Educación Pública, \\ Dr. Jiménez No. 47, Col. Doctores, Mexico City 06720, Mexico
}

\begin{abstract}
For the shrimp farming industry of Mexico, disease outbreaks caused by white spot syndrome virus (WSSV) are relatively recent. Efforts to control the virus are assisted by monitoring for its prevalence in aquaculture systems, but few attempts have been made to search for it in carriers from coastal waters. To search for WSSV carriers in the Gulf of California, we made surveys off the coast of Sinaloa, Mexico, in March 2001, November 2001, and September 2003 using polymerase chain reaction (PCR) assays and histopathology. WSSV-positive shrimp were detected only in November 2001, after hurricane Julliete. This suggested possible dispersal of WSSV to the marine environment from infected shrimp farms.
\end{abstract}

KEY WORDS: WSSV $\cdot$ Litopenaeus vannamei $\cdot$ Aquaculture $\cdot$ Gulf of California $\cdot$ Pacific white shrimp

Resale or republication not permitted without written consent of the publisher

\section{INTRODUCTION}

The shrimp-culture industry around the world has faced the problem of epizootics caused by more than 20 viruses (Lightner 1996). Of these, white spot syndrome virus (WSSV) has caused $100 \%$ mortality in many farms with consequent severe economic losses (Chou et al. 1998, Zarain-Herzberg 2000, De la RosaVelez \& Bonami 2002). In Mexico, WSSV has been reported since 1999 in cultured Litopenaeus vannamei (also called Penaeus vannamei) and in the crab Callinectes sapidus from drain channels in shrimp farms (López-Félix 2002). It is well known that the proliferation of shrimp diseases is increased by growth of the farming industry. The effluent from 1 farm recycled from the surrounding marine environment by adjacent farms is a common mechanism of disease dispersion, especially via marine fauna, if there is not a strict control of water discharge from aquaculture facilities (Lightner 1996, Lyle-Fritch \& Romero-Beltrán 2002). The objective of our research was to determine the prevalence of WSSV to captured L. vannamei from coastal waters adjacent to an area of high shrimpaquaculture activity.

\section{MATERIALS AND METHODS}

Three samplings were carried out during the fishing season onboard commercial shrimp trawlers operating off the northern coast of the Mexican state of Sinaloa, where a large number of shrimp farms operate (Fig. 1). A total of 424 individuals were taken (Table 1). Using the catch sequence, shrimp were numbered consecutively by trawl and their pleopods were dissected and placed in vials containing absolute ethanol for subse- 


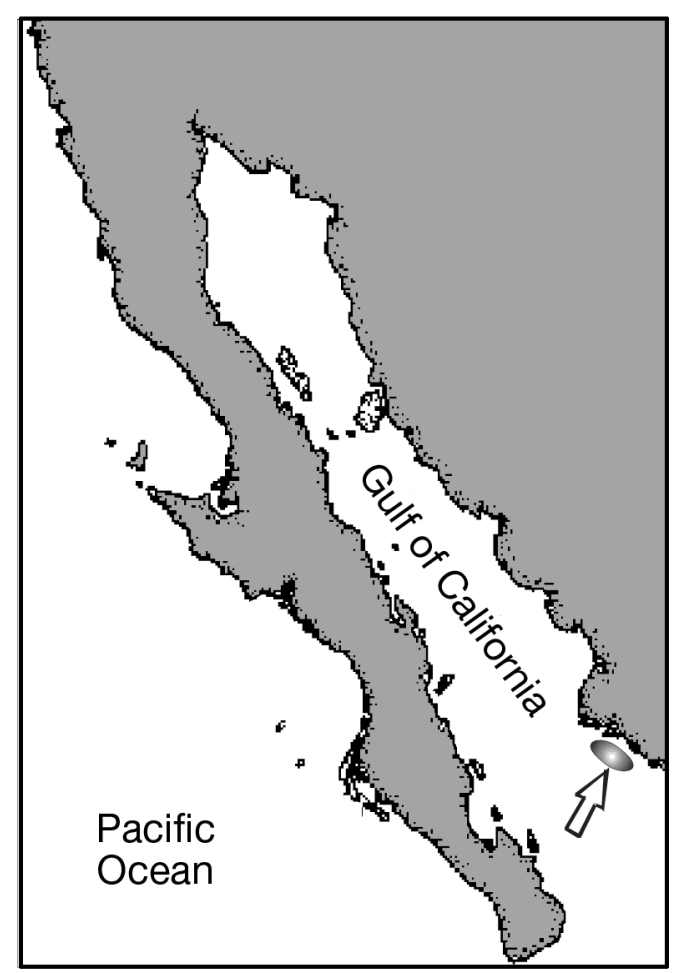

Fig. 1. Gulf of California showing sampling area (shaded ellipse) off the coast of northern Sinaloa, Mexico

quent polymerase chain reaction (PCR) analysis. For the histological analysis, the same shrimp were fixed with Davidson's solution while onboard the trawler and later transferred to $70 \%$ ethanol in the laboratory (Bell \& Lightner 1988).

For histological analysis, gastric epithelia and gills were inspected for the pathognomonic eosinophilic to basophilic intranuclear inclusions characteristic of WSSV infections (Karunasagar et al. 1997, Kasornchandra et al. 1998). For PCR analyses, the IQ2000WSSV kit was used following the manufacturer's instructions (Farming IntelliGene Technology). A first analysis was done in lots of 10 to 11 shrimp. When a positive result was obtained, individual shrimp were subjected to further PCR analysis. PCR products were observed in $2 \%$ agarose gels stained with ethidium bromide. In addition to the positive standard of the kit, we used a WSSV-positive shrimp from a nearby farm. All PCR runs also included a DNA-free sample for control.

\section{RESULTS AND DISCUSSION}

From the March 2001 sampling of 44 shrimp, no WSSV-positive samples were obtained using either PCR or histological analysis (Table 1). However, from the November 2001 sampling of 120 shrimp, 11 shrimp $(9.2 \%)$ were WSSV PCR-positive and 1 of these specimens showed typical WSSV inclusions in the gastric epithelium and gills (Fig. 2). The shrimp with histological signs of WSSV gave a PCR result indicating a severe infection (Fig. 3) while 6 shrimp had light infections and 4 had very light infections according to the diagnostic kit's scale. All 11 of the PCR-positive shrimp came from the same trawl. Shrimp collected in 2003 (260) were negative for WSSV by both PCR and histological analysis.

In Mexico, WSSV was found in shrimp from Sinaloa farms in 1999 (López-Félix, 2002) and we found WSSV positive samples in the natural environment in 2001. The impact of other viruses such as infectious hypodermal hematopoietic necrosis virus (IHHNV) and Taura syndrome virus (TSV) in both wild and cultured shrimp has been documented from the Gulf of California by Morales-Covarrubias et al. (1999) and ZarainHerzberg \& Ascencio-Valle (2001).

Although WSSV has been reported from Mexican shrimp farms, the scale of economic loss and the dispersion to wild populations has been poorly evaluated. Our sample of November 2001 with 9\% WSSV-positive shrimp from the western coastal zone of the Gulf of California, where aquaculture activity is high, sug-

Table 1. Sampling locations, dates and number of wild Litopenaeus vannamei analyzed for presence of WSSV. (1 fathom = $1.83 \mathrm{~m})$

\begin{tabular}{|c|c|c|c|c|c|}
\hline \multirow{2}{*}{$\begin{array}{l}\text { Location } \\
\text { Date }\end{array}$} & \multirow[t]{2}{*}{ Coordinates } & \multirow{2}{*}{$\begin{array}{c}\text { Fathoms } \\
\text { (no. of trawls) }\end{array}$} & \multirow[t]{2}{*}{ No. shrimp } & \multicolumn{2}{|c|}{ No. WSSV positive } \\
\hline & & & & Histology & PCR \\
\hline $\begin{array}{l}\text { Macapule } \\
\text { March } 2001\end{array}$ & $25^{\circ} 23^{\prime}-25^{\circ} 25^{\prime} \mathrm{N}, 108^{\circ} 52^{\prime}-108^{\circ} 56^{\prime} \mathrm{W}$ & $\begin{array}{c}5-10 \\
(4)\end{array}$ & 44 & 0 & 0 \\
\hline $\begin{array}{l}\text { Boca del Río } \\
\text { November } 2001\end{array}$ & $25^{\circ} 15^{\prime}-25^{\circ} 20^{\prime} \mathrm{N}, 108^{\circ} 35^{\prime}-108^{\circ} 25^{\prime} \mathrm{W}$ & $\begin{array}{l}5-10 \\
(8)\end{array}$ & 120 & $\begin{array}{c}1 \\
(0.8 \%)\end{array}$ & $\begin{array}{c}11 \\
(9.2 \%)\end{array}$ \\
\hline $\begin{array}{l}\text { La Palmita - Perihuete } \\
\text { September } 2003\end{array}$ & $25^{\circ} 03^{\prime}-25^{\circ} 21^{\prime} \mathrm{N}, 108^{\circ} 23^{\prime}-108^{\circ} 60^{\prime} \mathrm{W}$ & $\begin{array}{c}7-13.5 \\
(11)\end{array}$ & 260 & 0 & 0 \\
\hline
\end{tabular}




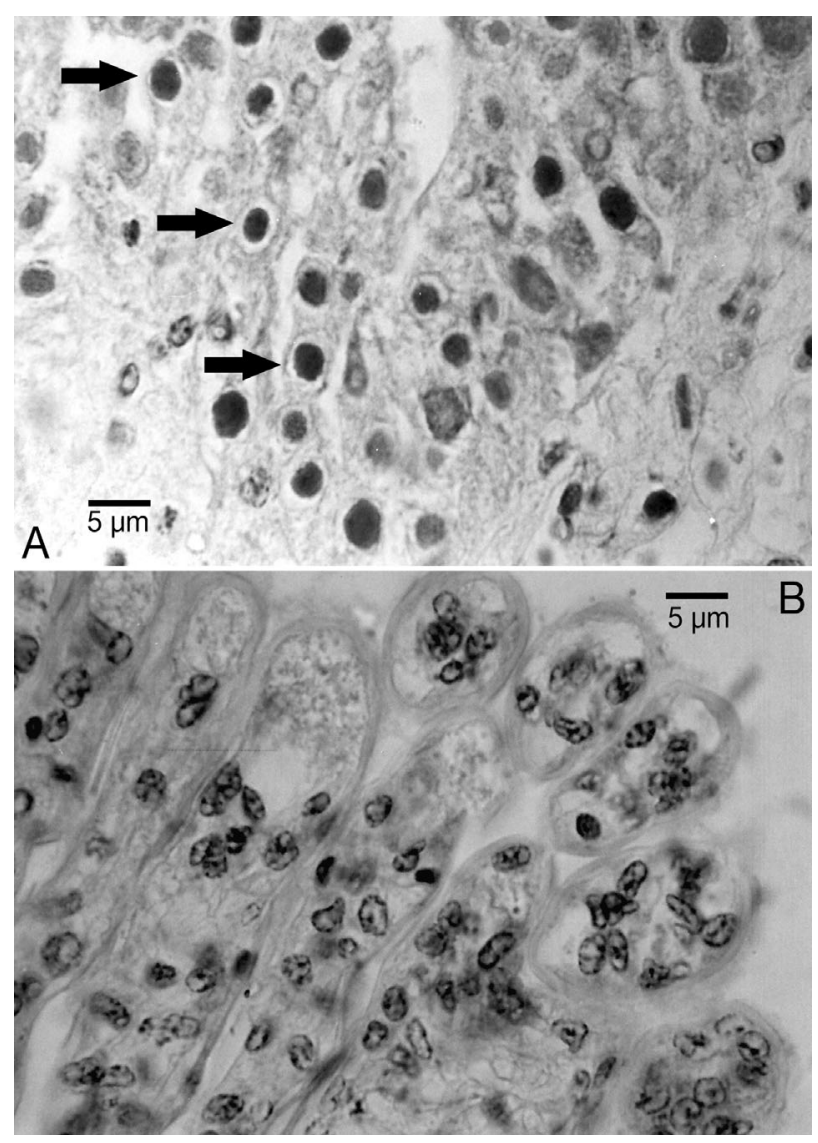

Fig. 2. Litopenaeus vannamei. (A) Photomicrograph of a gastric epithelium section of wild shrimp infected with white spot syndrome virus (WSSV) and showing typical WSSV inclusions (arrows). (B) Gill section of control (healthy) shrimp gests that there may be a risk of farm contamination from the wild. We believe that WSSV-positive shrimp in the wild may originate from nearby shrimp farms as uncontrolled escapes. This contention is supported by the facts that hurricane Julliete struck the Mexican Pacific coast, including the Gulf of California, from 21 September to 30 October 2001 and resulted in severe damage from Mazatlan in Sinaloa province to Yavaros in Sonora province on 28 October. All shrimp farms in that region suffered severe damage, probably resulting in the dispersal of farmed shrimp, including those infected with WSSV, into coastal waters. If this contention is correct, the lack of WSSV-positive shrimp in the sampling from 2003 suggests that WSSV may have a low impact on wild white shrimp.

To minimize the spread of viral diseases in cultured shrimp, the Mexican government decreed an official edict NOM-EM-003-PESC-2000 prohibiting the importation of WSSV-infected shrimp. However, the presence of captured shrimp infected with WSSV is of concern. A more extensive study should be implemented to determine the prevalence of WSSV in wild carriers along the Gulf of California coast and the degree of risk it might present to shrimp farmers. Potential carriers include not only shrimp, but also other crustacean species such as Callinectes spp., L. stylirostris (also called Penaeus stylirostris), and Farfantepenaeus californiensis (also called Penaeus californiensis), which are also known to be susceptible to WSSV infection (Otta et al. 1999). To reduce transmission risk, continuous surveillance for WSSV in wild populations may be implemented and barriers constructed to prevent carri-
A)

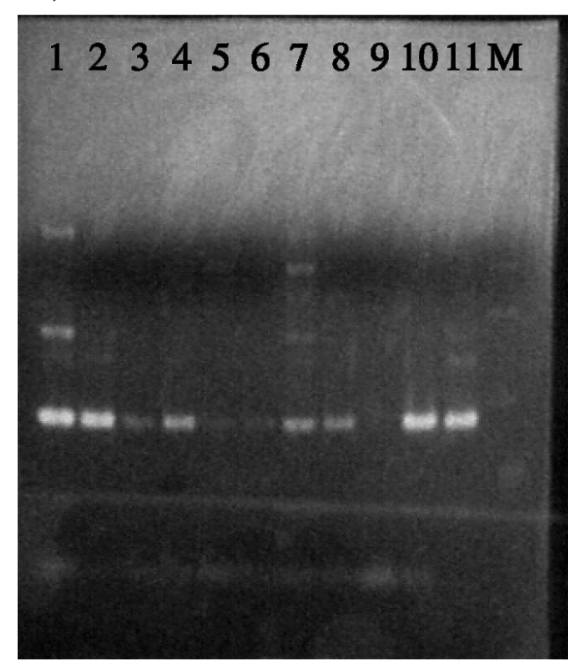

B)

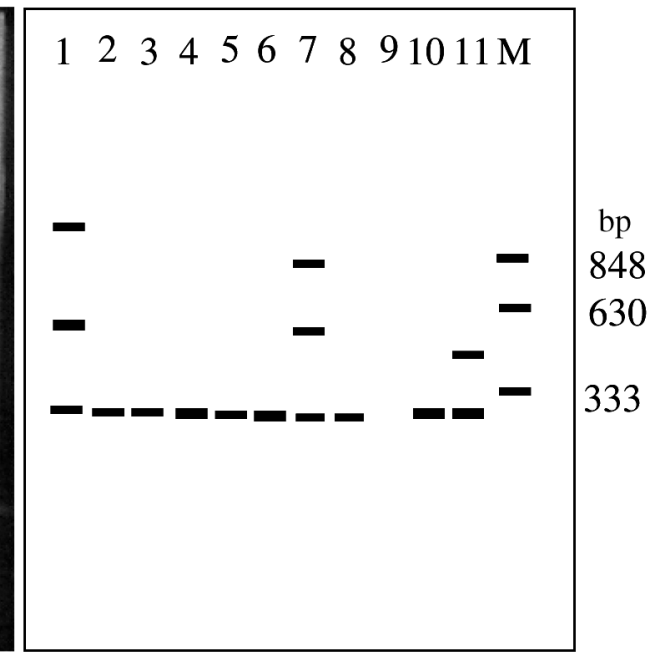

Fig. 3. Litopenaeus vannamei. (A) Scan and (B) drawing interpretation of agarose gel of PCR amplicons from 8 individual shrimp from a WSSV PCR-positive lot of 10 shrimp. Individuals showed severe (Lane 1), light (Lanes 2 to 6, 8), and very light (Lane 7) infections according to the kit manual. Lane 9: negative control. Lanes 10 and 11: positive standards (light and medium infections). M: molecular standard 
ers from entering and leaving culture ponds. The results from our study may also give some insight into the relative potential impacts of shrimp diseases and overfishing on the current shrimp fishery industry crisis in the Gulf of California (Lyle-Fritch et al. 2001).

Acknowledgements. Thanks to I. Cervantes, O. Valdéz, and the crew of 'Lobos III' for their assistance in field activities. Thanks to E. Glazier for editing this English-language text. We acknowledge a grant to Z.M.-A. and N.Q.-A. from Consejo Nacional de Ciencia y Tecnología.

\section{LITERATURE CITED}

Bell TA, Lightner DV (1988) A handbook of normal penaeid shrimp histology. World Aquaculture Society, Baton Rouge, LA

Chou HY, Huang CH, Lo CF, Kou GH (1998) Studies on transmission of White Spot Syndrome associated baculovirus (WSBV) in Penaeus monodon and P. japonicus via waterborne contact and oral ingestion. Aquaculture 164: 263-276

De la Rosa-Vélez J, Bonami JR (2002) Herramientas moleculares: una estrategia para la prevención de epizootias virales. In: Martinez-Cordova LR (ed) Avances y Tendencias en Camaronicultura. AGT Editor, SA Mexico City, p 83-110

Karunasagar I, Otta SK, Karunasagar I (1997) Histopathological and bacteriological study of white spot syndrome of Penaeus monodon along the west coast of India. Aquaculture 153:9-13

Kasornchandra J, Boonyaratpalin S, Itami T (1998) Detection of white-spot syndrome in cultured penaeid shrimp in Asia: microscopic observation and polymerase chain reac-

Editorial responsibility: Timothy Flegel, Bangkok, Thailand tion. Aquaculture 164:243-251

Lightner DV (1996) A handbook of shrimp pathology and diagnostic procedures for diseases of cultured penaeid shrimp. World Aquaculture Society, Baton Rouge, LA

López-Félix SC (2002) Determinación y evaluación por PCR, de la presencia del virus del síndrome de la mancha blanca (WSSV), en unidades de producción camaronícola del estado de Sinaloa. MS dissertation, Centro de Investigación en Alimentación y Desarrollo, A.C. Mazatlán, Sinaloa

Lyle-Fritch L, Romero-Beltrán E (2002) Informe sobre las prácticas de manejo en el cultivo del camarón en Sinaloa, México. Conservación Internacional, SEMARNAT, Instituto Nacional de la Pesca, Mazatlán, Sinaloa

Lyle-Fritch L, Romero-Beltrán PE, Bect-Valdez JA (2001) Desarrollo y Características de las granjas camaronícolas en Sinaloa, México. In: Paez-Osuna F (ed) Camaronicultura y Medio Ambiente. UNAM, Programa Universitario de Alimentos y El Colegio de Sinaloa, Mexico City, p 350-369

Morales-Covarrubias MS, Nunan LM, Lightner DV, MotaUrbina JC, Garza-Aguirre MC, Chávez-Sánchez MC (1999) Prevalence of Infectious Hypodermal and Hematopoietic Necrosis Virus (IHHNV) in wild adult blue shrimp Penaeus stylirostris from the northern Gulf of California. J Aquat Anim Health 11:296-301

Otta SK, Shubha G, Joseph B, Chakraborty A, Karunasagar I, Karunasagar I (1999) Polymerase chain reaction (PCR) detection of white spot syndrome virus (WSSV) in cultured and wild crustaceans in India. Dis Aquat Org 38:67-70

Zarain-Herzberg M (2000) Técnicas de diagnóstico de enfermedades en acuicultura. In: Bonilla Z, Burciaga I (eds) Memorias del III Simposium Internacional de Acuacultura. October 5-7, 2000. Once Ríos Editores, Culiacan, p 23-242

Zarain-Herzberg M, Ascencio-Valle F (2001) Taura Syndrome in Mexico: follow-up study in shrimp farms of Sinaloa. Aquaculture 193:1-9

Submitted: June 23, 2005; Accepted: January 4, 2006 Proofs received from author(s): June 21, 2006 